\title{
A new genus and species of deep-sea glass sponge (Porifera, Hexactinellida, Aulocalycidae) from the Indian Ocean
}

\author{
Sabyasachi Sautya ${ }^{1 \dagger}$, Konstantin R. Tabachnick ${ }^{2, \ddagger}$, Baban Ingole ${ }^{1, \S}$ \\ I National Institute of Oceanography, Dona Paula, Goa, 403004, India 2 Institute of Oceanology Ac. of Sc. of \\ Russia, Nabimovsky 36, Moscow, 117997, Russia \\ † urn:lsid:zoobank.org:author:580EDE04-9E83-46E1-AD61-4768B3531504 \\ ‡ urn:lsid:zoobank.org:author:AC4DFA99-C61A-45C5-A41F-746736EF63EF \\ § urn:lsid:zoobank.org:author:575B6C4E-B6B7-49F6-A53E-23688D087C2C \\ Corresponding author: Sabyasachi Sautya (sabya_aqua@rediffmail.com)
}

Academic editor: R. Pronzato | Received 30 May 2011 | Accepted 12 September 2011 | Published 13 October 2011

urn:lsid:zoobank.org:pub:E55BECD1-D81E-4713-A7E5-5FA7F5DEA6C7

Citation: Sautya S, Tabachnick KR, Ingole B (2011) A new genus and species of deep-sea glass sponge (Porifera, Hexactinellida, Aulocalycidae) from the Indian Ocean. ZooKeys 136: 13-21. doi: 10.3897/zookeys.136.1626

\begin{abstract}
New hexactinellid sponges were collected from $2589 \mathrm{~m}$ depth on the Carlsberg Ridge in the Indian Ocean during deep-sea dredging. All fragments belong to a new genus and species, Indiella gen. n. ridgenensis sp. n., a representative of the family Aulocalycidae described here. The peculiar features of this sponge, not described earlier for other Aulocalycidae, are: longitudinal strands present in several layers and epirhyses channelization.
\end{abstract}

\section{Keywords}

Porifera, Hexactinellida, Aulocalycidae, glass sponge, new genus, new species, Carlsberg Ridge, Indian Ocean

\section{Introduction}

The family Aulocalycidae was established by Ijima (1927) for 5 genera (Fig. 1): Aulocalyx Schulze, 1886, Rhabdodicyum Schmidt, 1880, Tretopleura Ijima, 1927, Euryplegma Schulze, 1886 and Fieldingia Kent, 1870. One genus Ijimadyctyum Mehl, 1992 was

Copyright Sabyasachi Sautya et al. This is an open access article distributed under the terms of the Creative Commons Attribution License, which permits unrestricted use, distribution, and reproduction in any medium, provided the original author and source are credited. 


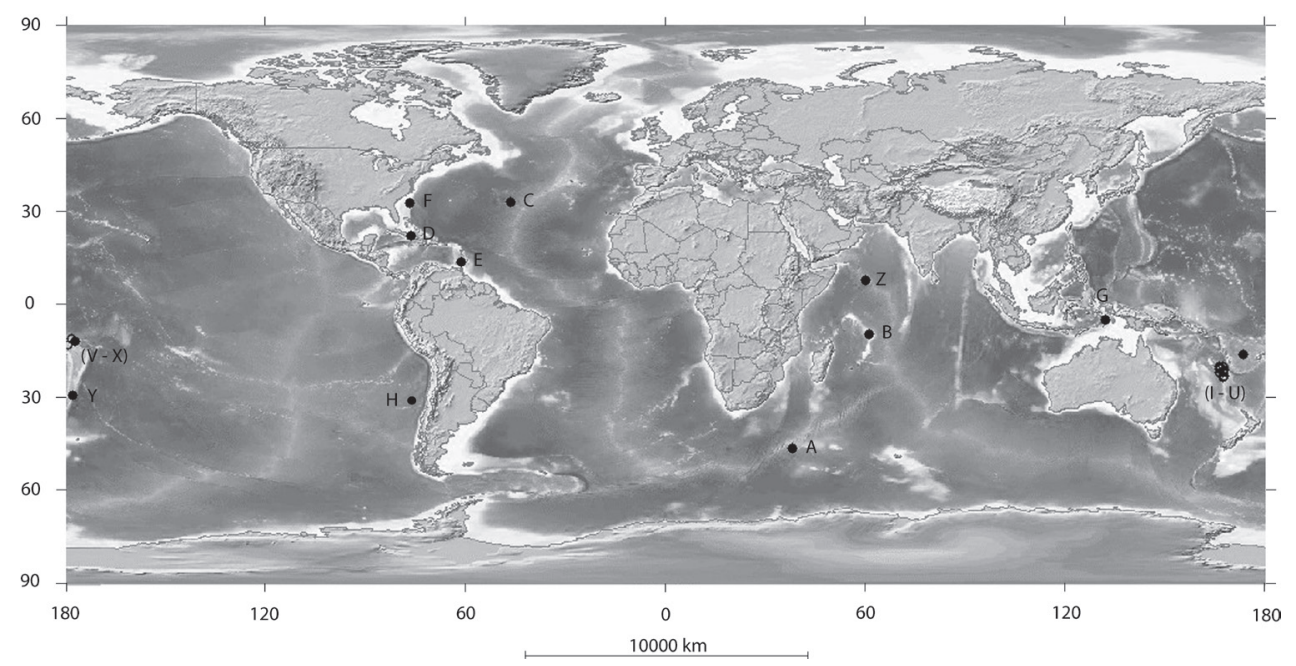

Figure I. Global distribution of Aulocalycidae including the present study A Aulocalyx irregularis B Aulocalyx serialis $\mathbf{C}-\mathbf{F}$ Rhabdodictyon delicatum $\mathbf{G}$ Ijimadyctyum kurense $\mathbf{H}$ Leioplegma polyphyllon $\mathbf{I}-\mathbf{Y}$ Euriplegma auriculare $\mathbf{Z}$ Indiella gen.n. ridgenensis sp.n.

raised from a previously known second species, Rhabdodicyum kurense Ijima, 1927. One genus was added later Leioplegma Reiswig \& Tsurumi, 1996. Tabachnick and Reiswig (2000) ejected two genera: Tretopleura and Fieldingia form the family and a suggested a new order Aulocalycoida with a single reorganized family. A new subfamily Uncinateriinae with two genera: Uncinatera, Topsent, and Tretopleura were suggested by Reiswig (2002) as a subdivision of Aulocalycidae together with Aulocalycinae (with the scope and definition of former Aulocalycidae of Tabachnick and Reiswig (2000)). A new subfamily Cyathellinae of the family Aulocalycidae with the only genus Cyathella Schmidt, 1870 was suggested by Janussen and Reiswig (2003). The new genus, describing in this paper is a unquestionable representative of the family Aulocalycidae sensu Tabachnick and Reiswig (2000) and subfamily Aulocalycinae sensu Reiswig (2002).

\section{Taxonomy}

\section{Family Aulocalycidae Ijima, 1927}

\section{Indiella gen. $\mathbf{n}$.}

urn:Isid:zoobank.org:act:DDD70A14-F35A-4F19-99A1-B58720834CF5

http://species-id.net/wiki/Indiella

Diagnosis. Fan (or funnel)-like basiphytous sponge with thin walls and numerous epirhyses. Framework contains several layers of regular dictyonal strands (mainly from the atrial side) and irregular fused hexactinic spicules (which form a typical aulocaly- 
coid skeleton) located among them and from the dermal side. Dermalia and atrialia are pentactins. Microscleres are discohexasters.

Etymology. The name of the genus is derived from its place of collection and refers to the Indian Ocean.

Definition. Aulocalycidae with fan (or funnel)-like body, epirhyses, and several regular layers of dictyonal strands located mainly on the atrial side.

Remarks. It is likely that the body is rather fan-like than cup or funnel-like since the fragments are flat, thus the funnel-like body shape should be of a very large diameter. The original shape of the body is already known in Aulocalycoidae: Leioplegma Reiswig \&Tsurumi, 1996, while wide funnels are unknown. Basiphytous type of fixation to likely hard substratum is suspected since all other representatives of the family have it. The taxonomic affiliation of genus Cyathella (its attribution to the Aulocalycoida, Aulocalycidae with definition of a new subfamily Cyathellinae was made by Janussen and Reiswig 2003), possessing a rhizophytous type of fixation is unique for recent hexactinellids with rigid skeleton.

The walls in the new genus are relatively thick (in comparison with other representatives of the family). Usually the aulocalycoid skeleton is composed of large hexactins located approximately in a single layer, their rays are distributed in a single plane (the distal one and proximal are bent), fusion takes place at points of mutual contact, so the wall thickness includes an only dictyonal layer. The regular dictional strands are observed in Leioplegma only, they are present as a single layer of parallel units longitudinally distributed, and irregular aulocalycoid skeleton is situated among them (Reiswig and Tsurumi 1996). The walls in Euryplegma appear to be very complicated and their construction has no equivalent interpretation (Tabachnick and Reiswig 2000). Cyathella has similar framework construction with several layers of dictyonal strands, but it has no channels and likely no loose spicules.

The presence of epirhyses type of channelization is unique for the family. It is known in Euretidae (Hexactinosida), for instance, in Chonelasma (Reiswig \& Wheeler, 2002). Among the other types of channelization in Aulocalycoidae, only schizorhyseslike ones are known in Euryplegma, meantime as in the case with complicated wall construction, they may be intercavaedia-like constructions between the atrial cavity and numerous small lateral oscula (Tabachnick and Reiswig 2000).

The loose spicules are typical for the family where few species possess scepters and uncinates. A more simplified spicule set is observed in Heterochone (Hexactinosida: Euretidae), which has no loose spicules other then discohexasters (Reiswig and Wheeler 2002).

The situation with aulocalycoid, paraulocalycoid and skeleton of Cyathella-like construction (Reiswig 2002 b; Janussen and Reiswig 2003) is becoming more complicated after finding in the dictional strands of Farrea numerous axial canals (Reiswig 2004), thus the definition of Aulocalycidae into subfamilies seems to be poorly established and the new genus is regarded as a representative of Aulocalycidae.

Type species. Indiella ridgenensis sp.n. 


\section{Indiella ridgenensis sp.n.}

urn:lsid:zoobank.org:act:185CC226-9FF5-42C9-8EA1-999CB8EF1146

http://species-id.net/wiki/Indiella_ridgenensis

Figs 2-4

Etymology. The species name is derived from its type locality, the ridge (Carlsberg Ridge) habitat.

Material examined. Carlsberg Ridge, Indian Ocean: 'Akademic Bois Petrov' station. DR-13, 0700.466'N, 5956.295'E, 2589 m, November 2009.

Holotype. NIO/BOD/5-H/2011, stored in ethanol. NIO/SPONGE/DR-13/H, slide, stored in ethanol. IORAS (Institute of Oceanology of Russian Academy of Sciences) 5/2/ NIO/BOD/5-H/2011 (slides).

Paratypes: NIO/BOD/5-P1, NIO/BOD/5-P2, NIO/BOD/5-P3, stored in ethanol. NIO/SPONGE/DR-13/Pi, NIO/SPONGE/DR-13/Pii, NIO/SPONGE/DR13/Piii, slides. IORAS NIO/BOD/5-P1, NIO/BOD/5-P2, NIO/BOD/5-P3, slides.

Description. Body: The sponge consists of small, lamellate, thin fragments. The holotype is a flat fragment approximately $40 \times 17 \mathrm{~mm}$ about $1 \mathrm{~mm}$ in thickness (Fig. 2i). Paratypes are similar: $\mathrm{Pi}$ is a lamellum $20 \times 25 \mathrm{~mm}$ (Fig. 2ii); Pii is $30 \times 20 \mathrm{~mm}$ (Fig. 2iii); Piii is $50 \times 45 \mathrm{~mm}$ (Fig. 2iv). From the dermal side numerous epirhyses are observed, they are $1.3-1.5 \mathrm{~mm}$ (Fig. $4 \mathrm{C}$ ) in diameter and penetrate about a half of the wall thickness.

Spicules framework is seems to be constructed of different elements: regular, longitudinally directed dictyonal strands, located mostly in the vicinity of the atrial surface (approximately 4 layers) and irregular hexactins fused to each other and to the regular elements at points of mutual contacts, at all levels of the wall thickness. All framework surfaces are covered by very small spines, the free outer ray ends are conically pointed. The dictyonal strands are easily observed, they have diameter $0.09-0.12 \mathrm{~mm}$, beams between the strands are $0.03-0.07 \mathrm{~mm}$ in diameter. Free rays of the dictyonal strands are protruded atrially. The meshes between the dictyonal strands and their connecting beams are rather regular, usually rectangular, $0.3-0.5 \times 0.5-0.8 \mathrm{~mm}$. Adjacent hexactinic spicules located among the dictyonal strands are irregularly and sparsely distributed among their meshes, they are connected to the framework by a single ray (small hexactins with rays $0.07-0.12 / 0.003-0.006 \mathrm{~mm}$ ) and often at points of mutual contact (large hexactins with rays about $0.5 / 0.012-0.018 \mathrm{~mm}$ ). The meshes there are very irregular and of different sizes. The dictyonal strands may be also observed in the vicinity of dermal surface but due to numerous epirhyzes, they are not straight as those from the atrial surface.

Loose spicules: dermal and atrial pentactins are similar to each other, they always have a rudiment about $0.02 \mathrm{~mm}$ long instead of the ray directed outside the body, rough surface, their outer ends are clavate, rounded, lanceolate or sometimes conically pointed. Tangential rays of dermal pentactins are $0.102-0.432 \mathrm{~mm}$ long (Table 1$)$, the ray directed inside the body is $0.048-0.258 \mathrm{~mm}$ long (Table 1 ), the diameter of these 


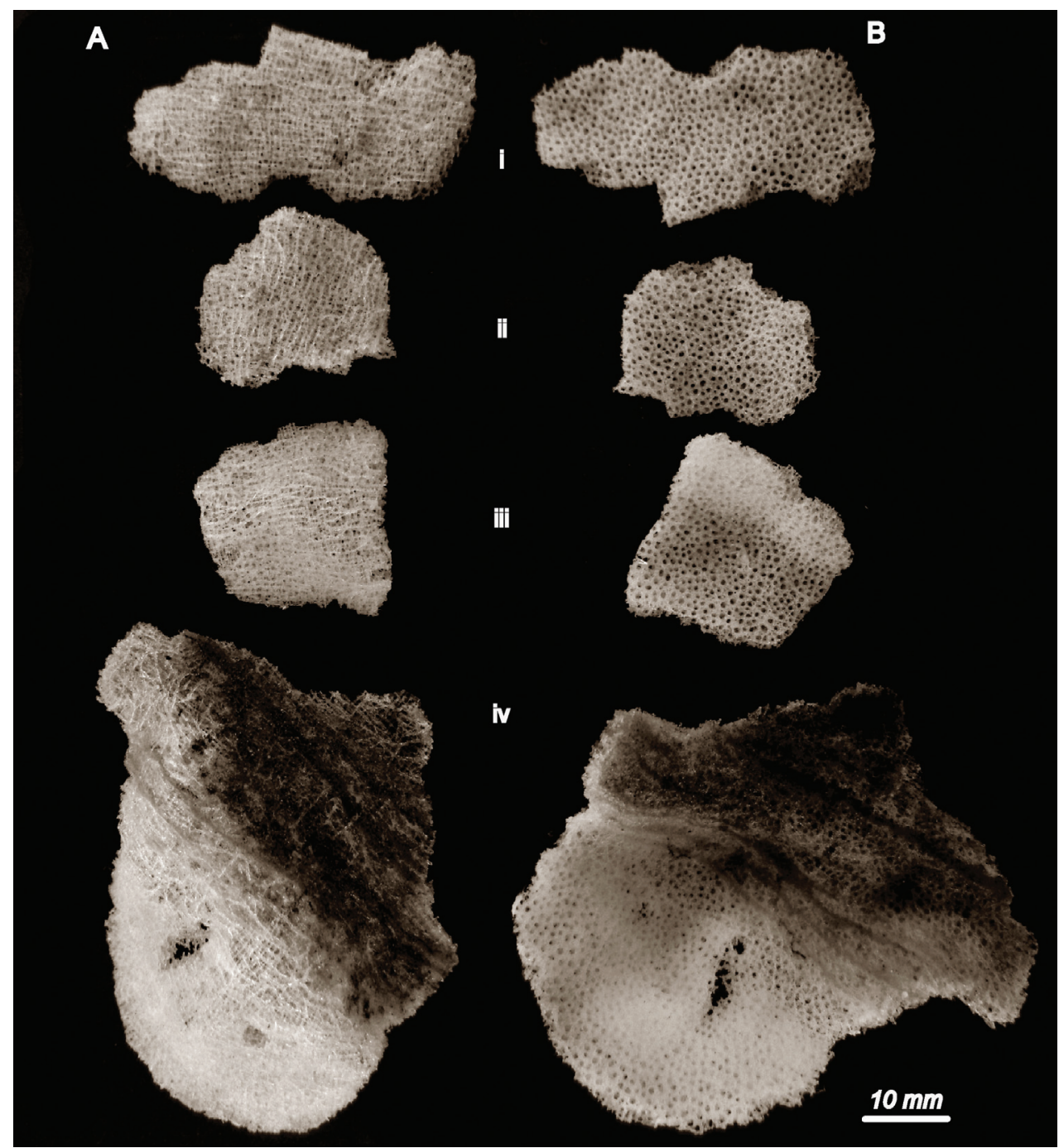

Figure 2. Indiella gen.n. ridgenensis sp.n. A view from the dermal side $\mathbf{B}$ view from the atrial side; (i) holotype, (ii) to (iv) paratypes

rays is $0.002-0.009 \mathrm{~mm}$. Tangential rays of atrial pentactins are $0.078-0.372 \mathrm{~mm}$ long, ray directed inside the body is $0.036-0.342 \mathrm{~mm}$ long (Table 1 ), the diameter of these rays is $0.004-0.009 \mathrm{~mm}$.

Microscleres are stellate discohexasters only, with 8-14 secondary rays. The diameter of the discohexaster is $0.025-0.046 \mathrm{~mm}$, their primary rosette is $0.006-0.018 \mathrm{~mm}$ in diameter (Table 1).

Remarks. Since all these fragments of the holotype and of paratypes were collected from the same station, there is a great probability that they belong to a single specimen. 
Table I. Spicule dimensions of Indiella gen. n. ridgenensis sp.n. (in mm). L - length, D - diameter, d diameter of a primary rosette $(\mathrm{N}=$ number of observations; Min = minimum; Max = maximum; Avg = average; $\mathrm{SD}=$ standard diviations). Bold measurements are used in the text sections.

\begin{tabular}{|c|c|c|c|c|c|c|c|}
\hline \multirow[t]{2}{*}{ Type } & & \multicolumn{2}{|c|}{ L Dermal pentactin } & \multicolumn{2}{|c|}{ L Atrial pentactin } & \multicolumn{2}{|c|}{ Discohexaster } \\
\hline & & \begin{tabular}{|l|} 
Tangential \\
ray
\end{tabular} & \begin{tabular}{|l|} 
Ray directed \\
inside body
\end{tabular} & \begin{tabular}{|l|} 
Tangential \\
ray
\end{tabular} & \begin{tabular}{|l|} 
Ray directed \\
inside body
\end{tabular} & \begin{tabular}{|l|} 
D \\
discohexaster
\end{tabular} & \begin{tabular}{|l|} 
d \\
discohexaster
\end{tabular} \\
\hline \multirow[t]{5}{*}{ Holotype } & $\mathrm{N}$ & 25.000 & 25.000 & 25.000 & 25.000 & 28.000 & 28.000 \\
\hline & Min & 0.102 & 0.060 & 0.078 & 0.042 & 0.025 & 0.006 \\
\hline & Max & 0.432 & 0.258 & 0.360 & 0.342 & 0.046 & 0.018 \\
\hline & Avg & 0.280 & 0.103 & 0.228 & 0.100 & 0.039 & 0.012 \\
\hline & SD & 0.099 & 0.048 & 0.081 & 0.067 & 0.005 & 0.003 \\
\hline \multirow[t]{5}{*}{ Paratype-1 } & $\mathrm{N}$ & 16.000 & 16.000 & 12.000 & 12.000 & 14.000 & 14.000 \\
\hline & Min & 0.168 & 0.048 & 0.108 & 0.060 & 0.032 & 0.009 \\
\hline & Max & 0.408 & 0.180 & 0.360 & 0.156 & 0.042 & 0.018 \\
\hline & Avg & 0.256 & 0.113 & 0.264 & 0.115 & 0.037 & 0.012 \\
\hline & SD & 0.070 & 0.049 & 0.076 & 0.032 & 0.003 & 0.002 \\
\hline \multirow[t]{5}{*}{ Paratype-2 } & $\mathrm{N}$ & 7.000 & 7.000 & 6.000 & 6.000 & 3.000 & 3.000 \\
\hline & Min & 0.240 & 0.078 & 0.132 & 0.048 & 0.039 & 0.012 \\
\hline & Max & 0.414 & 0.192 & 0.372 & 0.114 & 0.041 & 0.014 \\
\hline & Avg & 0.348 & 0.127 & 0.241 & 0.075 & 0.040 & 0.013 \\
\hline & SD & 0.060 & 0.039 & 0.095 & 0.023 & 0.001 & 0.001 \\
\hline \multirow[t]{5}{*}{ Paratype-3 } & $\mathrm{N}$ & 5.000 & 5.000 & 4.000 & 4.000 & 1.000 & 1.000 \\
\hline & Min & 0.168 & 0.072 & 0.150 & 0.036 & 0.032 & 0.008 \\
\hline & Max & 0.312 & 0.168 & 0.240 & 0.084 & 0.032 & 0.008 \\
\hline & Avg & 0.252 & 0.110 & 0.197 & 0.066 & 0.032 & 0.008 \\
\hline & SD & 0.067 & 0.037 & 0.038 & 0.021 & - & - \\
\hline
\end{tabular}

\section{Key to the Genera of Aulocalycidae}

$1 \quad$ Dictyonal strands not obvious, likely entirely absent (if present they are distributed chaotically), choanosomal hexactins fuse at points of mutual contacts, their distal and proximal rays are bent in the tangential plane (aulocalycoid skeleton)

- Dictyonal strands present in addition to aulocalycoid skeleton, dictyonal strands are distributed in common, longitudinal direction ..........................5

2 Body of branching tubes or cup with short lateral tubes............................ 3

- $\quad$ Body fan- or tongue-shape without tubular elements..................Euryplegma

3 With rhopalasters as distinctive microscleres ................................. Aulocalyx

- Without rhopalasters ..................................................................... 4

$4 \quad$ Parietal gaps large and closely spaced; wall lace-like............. Rhabdodictyum

- $\quad$ Parietal gaps small, sparse; wall thin and mostly imperforate... Ijimadictyum

$5 \quad$ Walls unchannelized .............................................................. Leioplegma

- Walls channelized by epirhyses.............................................. Indiella gen. $\mathbf{n}$. 


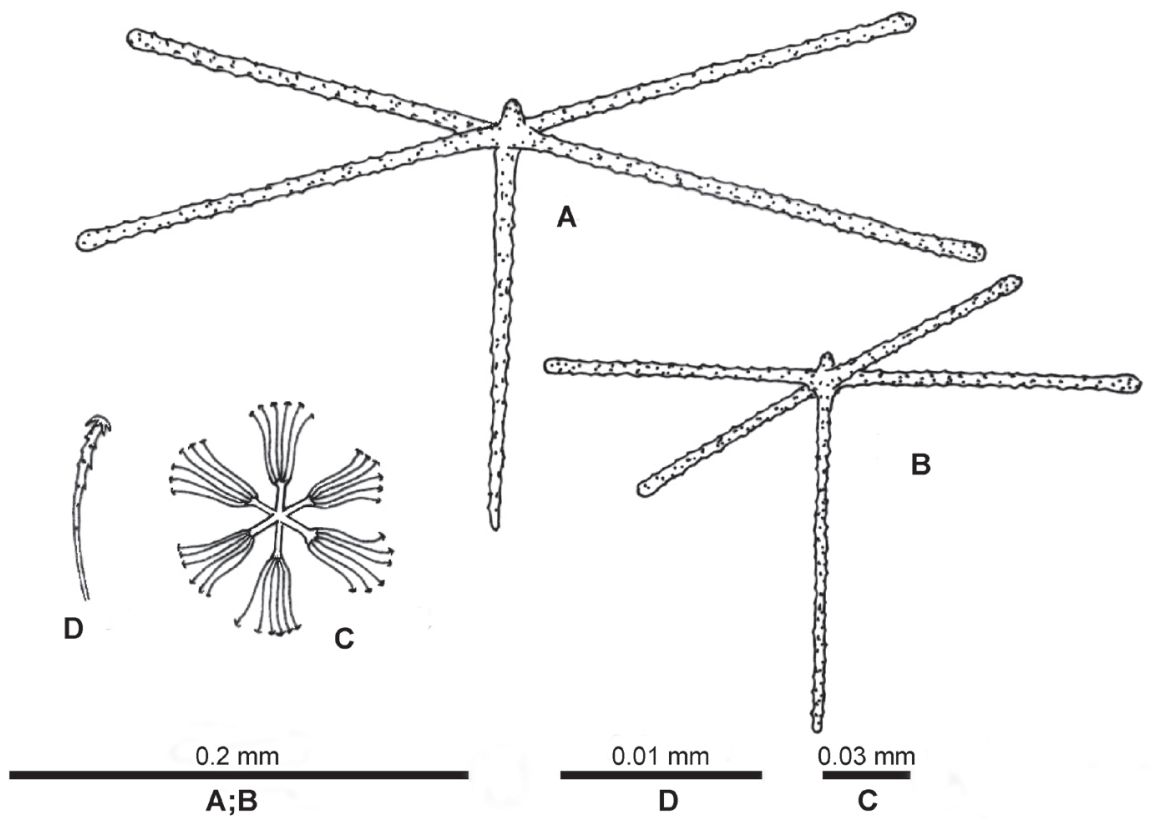

Figure 3. Indeilla gen n. ridgenensis sp.n. drawings of spicules of the holotypes $\mathbf{A}$ dermal pentactin $\mathbf{B}$ atrial pentactin, $\mathbf{C}$ discohexaster $\mathbf{D}$ secondary ray of discohexaster

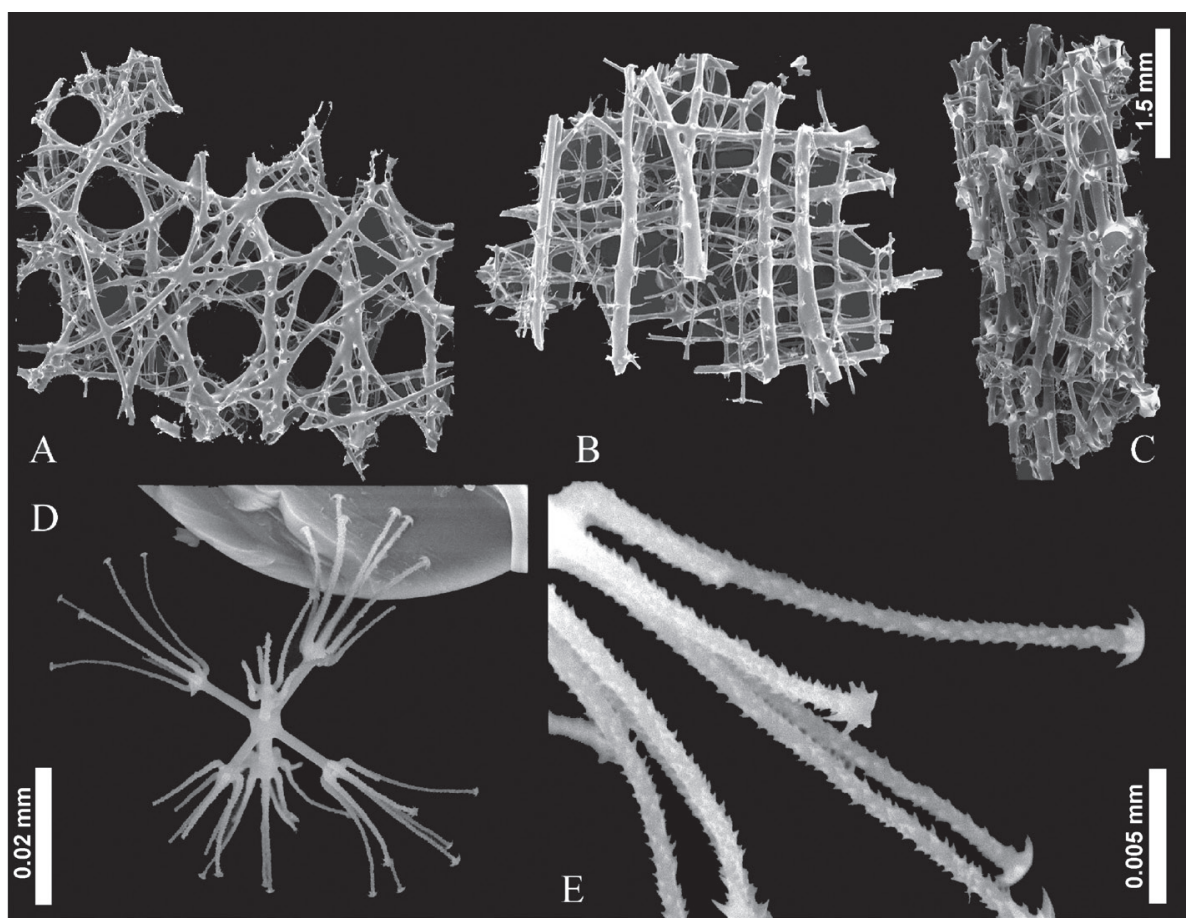

Figure 4. Scaning Electron Microscopy of Indeilla gen. n. ridgenensis sp. n. Frameowrk and spicules of the holotypes $\mathbf{A}$ dermal layer $\mathbf{B}$ atrial layer $\mathbf{C}$ lateral view $\mathbf{D}$ discohexaster $\mathbf{E}$ secondary ray tuft of discohexaster 
Remarks. It is not obvious that the genus Euryplegma has schizorhyses, as postulated in the key of genera by Reiswig (2002); a possibility of lateral oscula and cavaedia (Tabachnick and Reiswig 2000) cannot be rejected. This newly suggested version of the key to genera of Aulocalycoidae family avoids this problem.

\section{Acknowledgements}

The authors wish to express their gratitude to the Council of Scientific and Industrial Research (CSIR) for financial support to the Net-Work project 'Indian Ridge studies' We also thank the Director of NIO (Goa) for the facilities. We wish to acknowledge the team Leader Dr. Kamesh Raju and entire 'Ridge Group' for excellent team work during the deep-sea cruises. We also thank the Captain of the cruise 'Akademic Boris Petrov' and his group for help in collecting the priceless sample from the deep-sea. Our special thanks to Durbar Ray for collecting the samples and to Mr. VD Khedekar for help during Scanning Electron Microscopy at NIO, Goa, India. The senior author thanked CSIR for awarding the Senior Research Fellow which gave the opportunity to carry out this work. We gratefully acknowledge CenSeam (A Global Census of Marine Life on Seamounts - a CoML project) for travel support under the"CenSeam minigrant programme 2010" to analyze the sponge and associated fauna at P.P. Shirshov Institute of Oceanology of Russian Academy of Sciences, Moscow. Comments and suggestions from two anonymous reviewers helped in improving the manuscript. This is contribution No. 5040 of NIO (CSIR) Goa.

\section{References}

Ijima I (1927) The Hexactinellida of the Siboga Expedition. In:Weber M (Eds) Siboga-Expeditie. Uitkomsten op zoölogisch, botanisch, oceanographisch en geologisch gebied verzameld in Nederlandsch Oost-lndië 1899-1900 aan boord H.M. 'Siboga' onder commando van Luitenant ter zee 1e kl. G. F. Tydeman. 106 (Monographie VI). (E.J. Brill: Leiden): i-viii, $1-383$, pls I-XXVI.

Schulze FE (1886) Über den Bau und das System der Hexactinelliden. Abhandlungen der Königlichen Akademie der Wissenschaften zu Berlin (Physikalisch-Mathematisch Classe) 1886: 1-97.

Schmidt O (1880) Die Spongien des Meerbusen von Mexico (Und des caraibischen Meeres). Heft II. Abtheilung II. Hexactinelliden. Abtheilung III. Tetractinelliden. Monactinelliden und Anhang. Nachträge zu Abtheilung I (Lithistiden). In: Reports on the dredging under the supervision of Alexander Agassiz, in the Gulf of Mexico, by the USCSS 'Blake'. Gustav Fischer, Jena, 33-90, pls V-X. 
Mehl D (1992) Die Entwicklung der Hexactinellida seit dem Mesozoikum. Paläobiologie, Phylogenie und Evolutionsökologie. Berliner geowissenschaftliche Abhandlungen Reihe E (Paläobiologie) Berliner geowissenschaftliche Abhandlungen Reihe E (Paläobiologie) 2: $1-164$, pls 1-22.

Reiswig HM, Tsurumi M (1996) A new genus and species of Aulocalycidae, Leioplegma polyphyllon, (Porifera: Hexactinellida) from the Blake Ridge off South Carolina, U.S.A. Bulletin of Marine Science 58(3): 764-774.

Janussen D, Reiswig HM (2003) Re-description of Cyathella lutea Schmidt and formation of the new subfamily Cyathellinae (Hexactinellida, Aulocalycoida, Aulocalycidae). Senckenbergiana Biologica 82 (1/2): 1-10.

Tabachnick KR, Reiswig HM (2000) Porifera Hexactinellida: On Euryplegma auriculare Schulze, 1886, and formation of a new order. Mémoires du Muséum national d'Histoire naturelle (A, Zoologie) 184: 39-52.

Reiswig HM, Wheeler B (2002) Family Euretidae Zittel, 1877. In: Hooper JNA, van Soest RWM (Ed) (2002) 'Systema Porifera: A guide to the classification of sponges'. Kluwer Academic/ Plenum Publishers: New York, Boston, Dordrecht, London, Moscow, 1301-1331.

Reiswig H (2002) Hexactinosida incertae sedis. In: Hooper JNA, van Soest RWM (Ed) 'Systema Porifera: A guide to the classification of sponges'. Kluwer Academic/ Plenum Publishers: New York, Boston, Dordrecht, London, Moscow, 1355-1360. 
